\title{
Revisiting Shapero: A taxonomy of entrepreneurial typologies
}

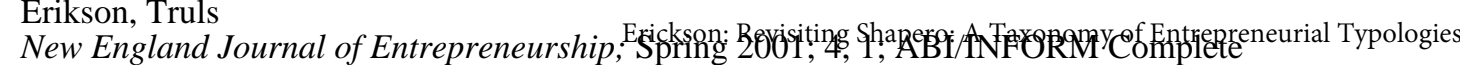
pg. 9

\section{Revisiting Shapero: A Taxonomy of Entrepreneurial Typologies}

\section{Truls Erikson}

The governing paradigm of industrial organization is the state of economic equilibrium. By contrast, Schumpeterian entrepreneurship creatively destructs such an equilibrium state. Moreover, Austrian entrepreneurship represents the arbitrage movement toward economic equilibrium. This interplay between movement toward and away from an equilibrium point is at the very heart of economic development and the evolution of industries. Those with the ability to deal with these movements toward and away from equilibria are entrepreneurs. That is, entrepreneurs' cognitive and behavioral ability to align their behavior with entrepreneurial opportunities is the fundamental mechanism to entrepreneurial supply. Based on the Shapero model, an entrepreneurial taxonomy is developed and implications are discussed.

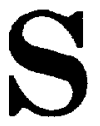

chumpeterian entrepreneurship is synonymous with the commercialization of radical innovations. When implemented in the marketplace, the result is that the economy is brought out of its equilibrium. By contrast, Austrian entrepreneurship illustrates how arbitrage spawns consequential movement toward economic equilibrium (Kirzner, 1997). This article makes the point that these movements, toward and away from economic equilibria, are a direct function of individuals' behavior, which is defined by their entrepreneurial abilities. Hence, what is labeled here as entrepreneurial ability is the individual's cognitive and behavioral capacity to exploit opportunities.

Austrian entrepreneurship could be said to represent the complementary cognitive and behavioral ability to perceive opportunities and to reallocate resources to meet situational demands. Although Austrian entrepreneurship begins with opportunity recognition (identification of a market gap), Schumpeterian entrepreneurship necessarily commences through the introduction of new combinations (e.g., a technology push). As Cheah (1990) pointed out, these two perspectives may also interact, because once a radical innovation reaches the market, there are ample opportunities for the Austrian-variety entrepreneurs to arbitrage away new market inefficiencies.

The Austrian perspective aligns with Schultz' (1975) call for an entrepreneurial framework which deals with the movement toward economic equilibria. Schultz argues that the ability to deal successfully with economic disequilibria - which is the ability to identify opportunities, and align resources to meet demands-can be enhanced through an improvement in cognitive abilities, acquired from education or experience, for example. Frameworks that analyze the function of this particular ability deal with the very heart of entrepreneurship. Moreover, Schultz' argues that these abilities should be treated as a scarce resource.

In analyzing equilibrating activities among people, Schultz (1975:833) postulates that there are economic incentives to reallocate resources, and that most people (entrepreneurs) respond to these incentives to the best of their ability. Schultz (1975:834) further states that these abilities represent the competence of people to perceive disequilibria (opportunities) and to assess its attributes properly in determining whether it is worthwhile to act. If the opportunity is perceived as worth acting upon, entrepreneurs will respond by reallocating available requisite resources--realizing economic gain as their reward.

A similar assertion can be made for those that perceive opportunities in the Schumpeterian sense. If the opportunity is determined worth pursuing, entrepreneurs will respond by developing or combining new resources; and the realized gains will, again, be their rewards.

Hence, the focus should be on potential (novice, serial or portfolio) entrepreneurs' perception of reality - their cognitive infrastructure. Within these conceptual frames, a taxonomy of potential entrepreneurs, which expands economic theory to include cognition and behavior, is developed and presented below.

\section{Conceptual Foundation}

According to Katz and Gartner (1988), entrepreneurial intentions may provide a theoretical framework for the emergence of new business organizations, as the emergence of new business organizations is dependent on individuals' intentions and their subsequent behavior. Gartner et al. (1994) argues that entrepreneurship is a process that evolves over time, and that entrepreneurial intentions can be seen as the first step in a medium- to long-term process of business formation. Krueger (1993) argues that entrepreneurial intentions are central to the process of entrepreneurship because they form the underpinnings of new organizations. At least three different models of behavior have been applied to entrepreneurship: 
1. Bird's model of intentionality (Bird, 1988; Boyd and Vozikis, 1994),

2. Ajzen's (1991) theory of planned behavior (e.g., Autio et al., 1997; Kolvereid, 1996), and

3. Shapero's (1984) model of the entrepreneurial event.

\section{Bird's Model of Intentionality}

Bird (1988) views intentionality as a state of mind directing a person's attention toward a specific object or a path in order to achieve a goal. Her model suggests that intention is based on both rational and intuitive thinking, and that social as well as personal contexts interact in the process of structuring intentions. She argues that rational-analytic thinking is goal directed and that intuitive-holistic thinking is vision oriented, and that such processes underlie the creation of formal business plans, opportunity analysis, and other goal-oriented behavior.

According to Bird, entrepreneurial intentions are a state of mind which directs and guides the actions of the entrepreneur toward the development and the implementation of new business concepts. Personal history such as mastery experience, vicarious experience, personality characteristics, and personal abilities, may predispose individuals toward entrepreneurial intentions. Similarly, social contexts such as government deregulation of industries or redundancies may also contribute to the formation of entrepreneurial intentions-both through rational analytic and cause-effect thinking processes and through intuitive, holistic and contextual thinking frames.

\section{Ajzen's Theory of Planned Behavior}

Krueger and Brazeal (1994) suggested that the AjzenFishbein (1980) model might offer a more robust model for the purpose of explaining or predicting entrepreneurial intentions. However, Ajzen's theory of planned behavior is an extension of Ajzen and Fishbein's (1980) theory of reasoned action, which also includes a competence assessment construct. Kolvereid (1996) demonstrated that the Ajzen (1991) framework is a solid model for explaining or predicting entrepreneurial intentions. Ajzen (1991) states that intention is the immediate antecedent of behavior. This conceptualization is congruent with Kim and Hunter's (1993) quest for an intermediate variable between attitude and behavior, based on their meta-analysis of more than 600 attitude-behaviour studies. According to Ajzen (1991), intentions are determined by three factors: (1) the attitude toward the behavior, which refers to the degree to which individuals perceive the attractiveness of the behavior in question; (2) the subjective norm, which refers to the perceived social pressure to perform the behavior in question; and (3) the perceived behavioral control (i.e. a self-evaluation of one's own competence with regard to the task or behavior).

\section{Shapero's Model of the Entrepreneurial Event}

Individuals' behavioral intentions are, according to Shapero's model of the entrepreneurial event, dependent on two main factors: perceived credibility (perceived feasibility and perceived desirability) and the propensity to act (see Exhibit 1). Shapero and Sokol (1982:83-86) conceptualized perceived desirability as the personal attractiveness of starting a business, and perceived feasibility as a perceptual measure of personal capability with regard to new venture creation. They used the term "credible" if entrepreneurship was seen as both desirable and feasible. Shapero's framework was later assessed by Krueger (1993). Both Shapero and Sokol (1982) and Krueger (1993) argued that perceived desirability, perceived feasibility, and propensity to act are associated with entrepreneurial behavioral intentions. Moreover, Krueger (1993) found that the model explained entrepreneurial intentions quite well.

Because these frameworks compete in explaining or predicting entrepreneurial intentions, and because they focus on different facets of the cognitive-behavioral infrastructure, they should be regarded as complementary analytical frameworks. Nonetheless, the focus in this article is on the more holistic framework initially proposed by Shapero. This summary review indicates that Shapero's framework of the entrepreneurial event is still worth investigating as the model provides a holistic framework for entrepreneurial intentions-a measure that precedes entrepreneurial behavior. Hence, this study proposes that the main independent variables in the Shapero model will influence the dependent variable entrepreneurial behavioral intentions. The two underlying directional propositions are:

Proposition 1: The higher the perceived venture desirability, the stronger the entrepreneurial behavioral intentions.

Proposition 2: The higher the perceived venture feasibility, the stronger the entrepreneurial behavioral intentions.

The other main component in Shapero's model is the proactivity component. Krueger (1993) empirically tested this model on 126 upper-division university business students. Krueger (1993) suggested that a disposition toward a propensity to act has an influence on entrepreneurial intentions. His findings support Shapero's model to a large extent, but he notably used a surrogate for the proactivity component, which was Burger's (1985) desirability of control. Due to the lack of appropriate constructs and instruments, Shapero suggested the locus of control measure. Moreover, Reitan (1996) employed a surrogate measure of the propensity to act component. In fact, Reitan used a change orientation index and an achievement motivation index as surrogate 


\section{Exhibit 1}

\section{Shapero's Model of the Entrepreneurial Event}

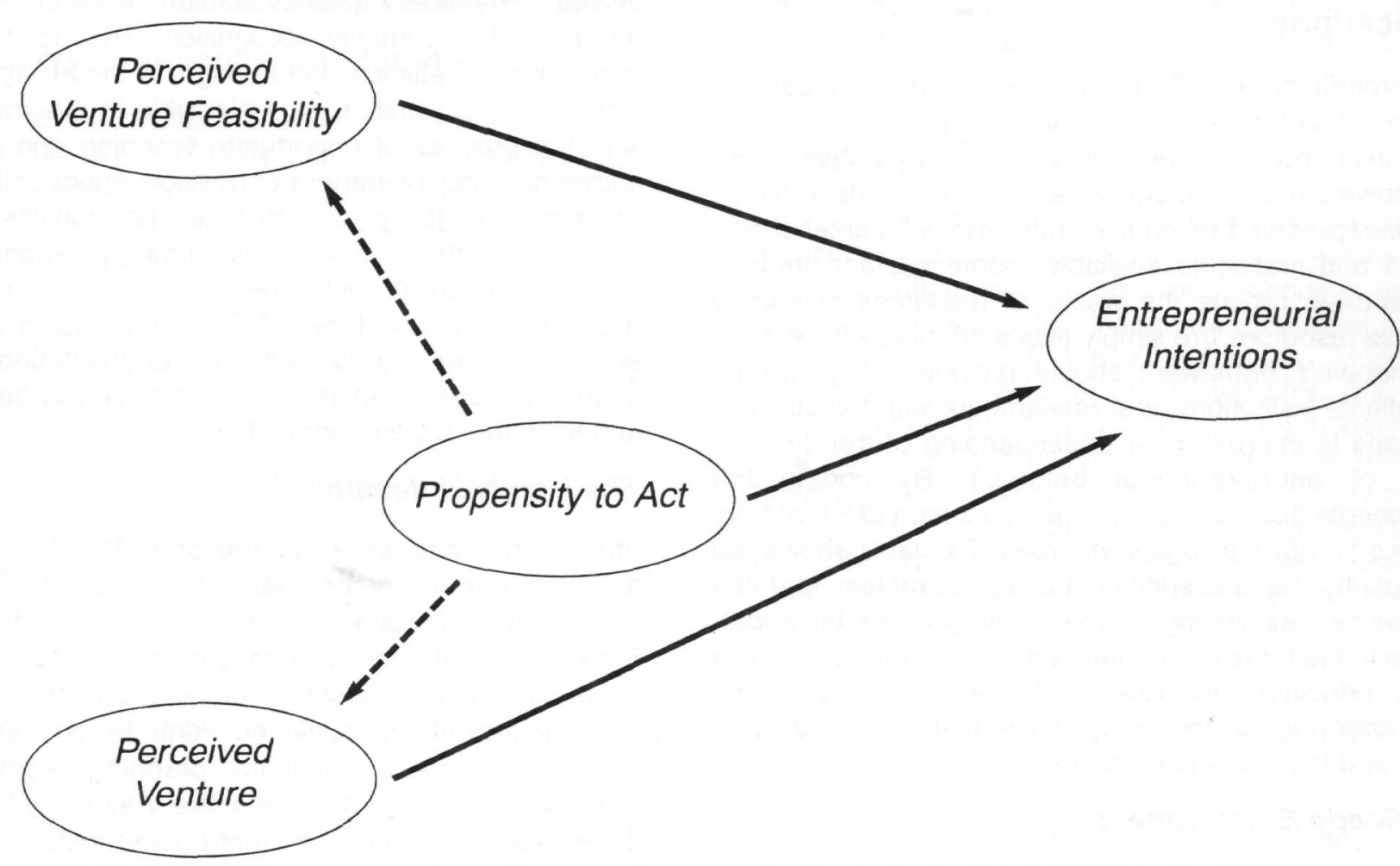

constructs, as both were expected to say something about an individual's predisposition toward business venturing.

By contrast, few studies concerning entrepreneurship have considered Bateman and Crant's (1993) component of proactive behavior in relationship to entrepreneurial behaviour. The propensity to act construct in Shapero's initial model refers to beliefs about personal control. Whereas it can be argued that Bateman and Crant's construct represents a more active measure, as this construct relates to opportunity identification - the propensity to act upon identified opportunities. For instance, Crant (1996) found that the proactivity component was positively related to entrepreneurial intentions based on a sample of 181 US students. Reitan (1996) conducted a larger, more representative survey, with 1315 respondents and found that the propensity to act component explained very little about entrepreneurial intentions. However, Krueger (1993) and Reitan (1996) used different measures, and neither used an opportunityorientated construct. Hence, Shapero's original model is still a highly interesting framework.

According to Shapero (1984), propensity to act is the disposition to act upon one's intention. Proactive behavior can also be defined as the tendency to affect environmental change (Bateman and Crant, 1993). The point is that the propensity to act will influence the environment. According to the interactionist perspective (Bandura, 1997; and Bowers, 1973), individuals with a disposition for proactive behavior have a tendency to attempt to change or create their own environment. It is argued that they also do this faster than others. It is further believed that proactive people will be more likely to succeed in their endeavors than those who are not proactive. Such a notion is also supported by statements from experienced business consultants (personal communications), who observe that those nascent entrepreneurs who create and organize in addition to thinking and talking are also those who are most often able to make the new venture operational. However, the extent to which a new business venture is successful is another issue. Bateman and Crant (1993) developed an instrument intended for measuring individuals' disposition to change or to create their own environment. Recent research by Crant (1996) indicates that the proactivity measure of organizational behavior is an interesting measure in entrepreneurial research. Crant suggested that prospective entrepreneurs are more likely to be proactive in behavior, and found support for this in his study. The proactivity component will positively influence entrepreneurial intentions. Hence, the underlying directional proposition is: 
Proposition 3: The higher the proactivity, the stronger the entrepreneurial behavioral intentions.

\section{Implications}

Entrepreneurial behaviour is argued to be the underlying engine of self-renewing economies (Shapero, 1981). Austrian entrepreneurship uses arbitrage to achieve movement toward economic equilibria. In other words, Austrian type entrepreneurs recognize undiscovered market opportunities and reallocate available resources, and through this process, reduce the waste of resources in society because resources are simply allocated more efficiently.

Shapero's framework should provide policy-makers, educational institutions, and researchers with the structural means to improve their understanding of the determinants of entrepreneurial behavior. By coding the antecedents dichotomously, a categorization different from Reitan's (1996) typologies emerges. Exhibit 2 shows the bureaucrat, the uncredibles, the undesirables, and the daydreamers as typologies where entrepreneurship apparently is in the horizon. To effectively create entrepreneurial supply, educators and researchers should focus on: the ready entrepreneur, the ready reluctant, the ready undesirables, and the ready unconvinced.

\section{The Ready Entrepreneur}

The Ready Entrepreneur is the proactive person who finds entrepreneurship both desirable and feasible. This is the typical entrepreneur focused on in the entrepreneurship research literature. Most of these are self-governed, able to continuously recognize new opportunities, and able to reallocate available resources to meet situational demands. Educators and researches should seek to assist these prospects with their endeavors by facilitating methods and tools for successful business creation.

\section{The Ready Reluctant}

These individuals find entrepreneurship personally desirable and feasible, but do not have a proactive attitude. These individuals might not act on an opportunity unless they are strongly encouraged. Educational institutions should attempt to train these individuals to better recognize and identify opportunities. As Krueger and Dickson (1994) pointed out, there is a strong relationship between perceived self-efficacy (self-evaluation of personal competence) and opportunity recognition. That is, the higher perceived self-efficacy, the stronger is the ability to recognize new opportunities. It is plausible that some practice with the process of opportunity scanning and a general knowledge and awareness of possible opportunities would enhance the ability to recognize opportunities. That is, educational institutions should strongly emphasize the Austrian notion of entrepreneurship, which holds that opportunities are "out there." They just have to be discovered. In other words, educational institutions should attempt to develop an individual's proclivity to be aware of and scan for viable opportunities.

\section{The Ready Unfeasible}

The Ready Unfeasible are the ones that find entrepreneurship personally desirable, but who perceive it as unfeasible despite their proactive disposition. Entrepreneurial endeavors may be perceived as unfeasible due to multiple reasons. For this group of people, educational institutions could concentrate on competence enhancement and feasibility planning. According to Bandura (1997), the most effective way for individuals to develop a strong sense of (entrepreneurial) competence is through mastery experience. Hence, realistic entrepreneurship training cases along with new venture internships could increase the perception of entrepreneurial competence among people. Observational learning is the second way to strengthen perceived entrepreneurial competence. The third way to strengthen perceived competence is through social persuasion. That is, through interaction with entrepreneurially orientated others.

\section{The Ready Unconvinced}

Those who are ready unconvinced find entrepreneurship undesirable in spite of both their proactive disposition and the fact that they see entrepreneurship as feasible. Only radical environmental changes may alter these perceptions. Nonetheless, for these people, educational institu-

\begin{tabular}{|c|c|c|c|c|c|c|c|c|}
\hline \multicolumn{9}{|c|}{$\begin{array}{c}\text { Exhibit } 2 \\
\text { A Typology Based on Shapero's Antecedents }\end{array}$} \\
\hline "Yes" or "No" & $\begin{array}{l}\text { The } \\
\text { Bureaucrat }\end{array}$ & $\begin{array}{c}\text { The } \\
\text { Uncredibles }\end{array}$ & $\begin{array}{c}\text { The } \\
\text { Undesirables }\end{array}$ & $\begin{array}{c}\text { The } \\
\text { Daydreamers }\end{array}$ & $\begin{array}{l}\text { The Ready } \\
\text { Unconvinced }\end{array}$ & $\begin{array}{l}\text { The Ready } \\
\text { Unfeasible }\end{array}$ & $\begin{array}{l}\text { The Ready } \\
\text { Reluctant }\end{array}$ & $\begin{array}{l}\text { The Ready } \\
\text { Entrepreneur }\end{array}$ \\
\hline Venture desirability & $N$ & $N$ & $N$ & $Y$ & $N$ & $Y$ & $Y$ & $Y$ \\
\hline Venture feasibility & $N$ & $N$ & $Y$ & $N$ & $Y$ & $N$ & $Y$ & $Y$ \\
\hline Proactive behavior & $N$ & $Y$ & $\bar{N}$ & $N$ & $Y$ & $Y$ & $N$ & $Y$ \\
\hline
\end{tabular}


tions could focus on making entrepreneurship more desirable. More knowledge of entrepreneurship, and exposure to successful entrepreneurial role models could perhaps modify their perception about entrepreneurship.

\section{Should Everyone Become and Entrepreneur?}

A relevant question arises with regard to the four latter typologies: Should everybody become an entrepreneur? Should educational institutions nurture entrepreneurial behaviour among all people, or target only those with the desire and/or talent for it? Consider, for example:

- Daydreamers, who would like to become entrepreneurs, but do not perceive it as feasible, nor do they have a proactive mindset

- Undesirables, who perceive entrepreneurship as feasible, but choose not to follow such a road, nor do they have a proactive mindset.

- Uncredibles, who perceive entrepreneurship as neither desirable nor feasible.
- Bureaucrats who probably will never become entrepreneurs.

Are not these typologies most probably better off with other types of employment? Instead, policy-makers could seek to stimulate a general favorable attitude toward entrepreneurship among these in general.

\section{Conclusions}

The identification of the above eight categories should enable policy-makers, educators, and researchers to develop more rigorous programs and methods to nurture each typology. As this article has shown, different means are needed to develop these typologies. Moreover, because entrepreneurship develops over time, it is likely that this model can function as the first step in identifying the potential for new firm formation-as entrepreneurial intentions precede behavior. This model also provides an appropriate framework for developing an early stage entrepreneurial career theory, which should, in part, align with Dyer's (1994) call for a theory of entrepreneurial careers.

\section{References}

Ajzen, I. 1991. "The theory of planned behavior." Organizational Behavior and Human Decision Processes. 50, pp.179-211

Ajzen, I., and M. Fishbein. 1980. Understanding attitudes and predicting social behavior. Prentice-Hall, Inc., Englewood Cliffs, N. J. USA.

Autio, E., R. H. Keeley, M. Klofsten, M., and T, Ulfstedt. 1997. Entrepreneurial Intent Among Students. Testing an intent model in Asia, Scandinavia and USA. In P. D. Reynolds, W. D. Bygrave, N. Carter, P. Daviđsson, W. B. Gartner, and P. P. McDougall (eds.). Frontiers of entrepreneurship research.

Bandura, A. 1997. Self-efficacy; the exercise of control. Freeman Press: New York.

Bateman, T. S., and J. M. Crant. 1993. "The proactive component of organizational behavior." Journal of Organizational Behavior, 14(2), pp.103-118.

Bird, B. 1988. "Implementing entrepreneurial ideas: The case for intention." Academy of Management Review, 13(3), pp. 442-453.

Bowers, K.S. 1973. "Situationism in psychology: An analysis and critique." Psychosocial Bulletin. 80, pp. 307-336.

Boyd, N., and G. S. Vozikis, G. S. 1994. The influence of self-efficacy on the development of entrepreneurial intentions and actions. Entrepreneurship Theory and Practice 18(4), pp. 63-77.

Cheah, H. 1990. "Schumpeterian and Austrian entrepreneurship: Unity within duality." Journal of Business Venturing, 5(6), pp. 341-341.

Crant, J. M. 1996. "The proactive scale as a predictor of entrepreneurial intentions." Journal of Small Business. 34(3), pp. 42-50.

Dyer, W.G. Jr. 1994. "Toward a theory of entrepreneurial careers." Entrepreneurship Theory and Practice, 19(2), pp. 7-21. 
Gartner, William., K. G. Shaver, E. Gatewood E., and J. Katz. 1994. "Finding the entrepreneur in entrepreneurship." Entrepreneurship Theory and Practice, 18(3), pp. 5-9.

Katz, J. A. 1992. "Psychological cognitive model of entrepreneurial choice." Entrepreneurship Theory and Practice, 17, pp. 29-36.

Kim, M. S., and J. E. Hunter. 1993. "Relationships among attitude, behavioral intentions, and behavior. A metaanalysis of past research" (Part 2). Communication Research. 20(3), pp. 331-364.

Kirzner, I. M. 1997. "Entrepreneurial discovery and the competitive market process: An Austrian approach." Journal of Economic Literature, 35, pp. 60-85.

Kolvereid, L. 1996. "Prediction of entrepreneurial employment status choice intentions." Entrepreneurship Theory and Practice, 21(1), pp. 47-57.

Krueger, N. F. Jr., and D. V. Brazeal. 1994. "Entrepreneurship potential and potential entrepreneurs." Entrepreneurship Theory and Practice, 19(3), pp. 91-104.

Krueger, N. F. Jr., and P. R. Dickson. 1994. "How believing in ourselves increases risk taking: Perceived self-efficacy and opportunity recognition. Decision Sciences, 25(3), pp. 385-400.

Krueger, N. F. Jr. 1993. The Impact of Prior Entrepreneurial Exposure on Perceptions of New Venture Feasibility and Desirability. Entrepreneurship Theory and Practice. Fall. pp. 5-19.

Reitan, B. 1996. A taxonomy of potential entrepreneurs. Paper presented at the 9th Nordic Small Business Research Conference, Lillehammer. Norway.

Schultz, T. W. 1975. "The value of the ability to deal with disequilibria." Journal of Economic Literature, 13(3), pp. 827-846.

Schumpeter, J. A. 1936. Theory of economic cevelopment. Cambridge: Harvard University.

Shapero, A. 1981. "Self-renewing economies." Economic Development Commentary, 5, pp. 19-22.

Shapero, A. 1984. The Entrepreneurial Event. In Kent, C.A. (ed.), Environment for entrepreneurship,.Lexington, MA: D.C. Heath., pp. 21-40.

Shapero, A., and L. Sokol. 1982. The social dimension of entrepreneurship. In Kent, C. A, D. L. Sexton, and K. H. Vesper, Encyclopedia of entrepreneurship. Prentice Hall, Englewood, NJ.
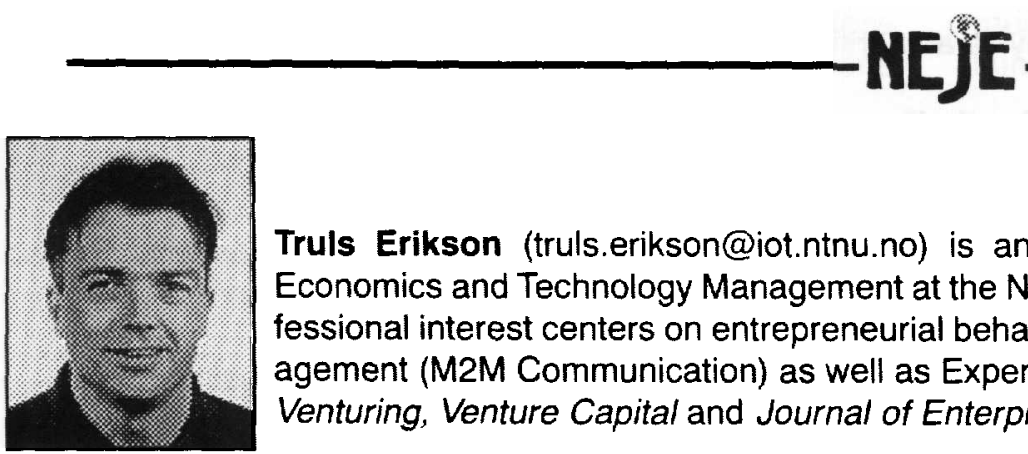

Truls Erikson (truls.erikson@iot.ntnu.no) is an associate professor in the Department of Industrial Economics and Technology Management at the Norwegian University of Science and Technology. His professional interest centers on entrepreneurial behavior, corporate finance, venture capital, technology management (M2M Communication) as well as Experts in Team. He has published in the Journal of Business Venturing, Venture Capital and Journal of Enterprising Culture. 